The Cry of the Common Frog

In NATURr, vol. x. p. $46 \mathrm{r}, \mathrm{Mr}$. Mott notices the cry of the common frog when annoyed. One of the greatest enemies of this frog in the United States is the common striped snake (Tiopidonotus tenia, Dekay). He seizes the frog by the hind legs for the purpose of swallowing him, when the latter will utter a most pitiful cry. I have detected them in this condition at a distance by the frog's note. I have amused myself by taking a frog by the hind legs and dragging him slowly backwarts on the ground in a serpentine direction, when he will exhibit his characteristic wail to perfection; and, when released, he will frequently utter some apparently intelligent imprecations as he hops off out of reach. I have noticed the same effect produced by a playful kitten armusing itself by teasing the frog, seemingly for the purpose of hearing him cry. Sliding a stick after him like a snake will produce the same results in a still more striking manner.

Oswego, U.S., Oct. 29

A. T. T:

\section{Phylloxera Vastatrix}

CAN any of your readers kindly inform me where a specimen of Phylloxera vastatrix can be obtained?

Epswich

\section{A. IIARWOOD}

\section{A Nest of Young Fish}

Wint on the point of taking my accustomed morning plunge in one of the clear pebbly streams that find their way into the plains from the northern mounta'n ranges of the island of Trinidad, my attention was attracted by the eccentric movement of a small fish of the perch tribe. In general this fish is extremely shy, scudding off into deep water or under some ovethanging bank on the approach of man; on this occasion, however, on putting ny hand into the water, the fish, to my astonishment, darted forward again and again, striking my hand with considerable force. Rather at a loss to account for such temerity in a fish only 4 in. long, I watched its movements narrowly, and at list fonnd out the cause. In a small hollow close by, about the size of half an egg, artistically excavated from the bright quartz sand, a multitude of tiny fish were huddled together, their minute fin. and tails in constant motion. They had apparently been only very recently hatched, and were no larger than common house flies; the parent fish kept jealous watcix over her proseny, resenting any attempt on my part to touch them.

Next morning, accompanied by my father and bro:hers, I returned to the spot which I had carefully marked the day befure. For some time, however, we searched in vain for the fish and her young ; at length, a few yards further up stream, we discovered the parent guarding her fry with zealous care in a cavity similarly sccoped out of the coarse sand; any attenyt. to introtuce one's fincer into the hollow was vigorously opro-e by the watchful mother. This is the first and only instance that has come under my notice of a fish watching over her young, an. conveying them, when threatened by danger, to some other place. The clear streams that flow along the valleys amont the northern mountain ranges of the island abound with fish of the val iety I refer to; they are in general of a bripht yellowish brown, th the or more silvery stripes on the sides, and reldom exced five inches in length; but in the sluggish turbid rivers of the plains, the bright colours change to a dull brown; the fish are larrer, however, varying in size from eirht to ten inclues. Extremely tenacious of life, these fish, in common with severa other species, have the power of extsting in a semi-torpid state for weeks, and even months, buried during severe droughts in the nuud of dry watercourses, where they are dug up by the Creole peasants, who prize them as food; but from the peculiar earthy flavour common to many varieties of freshwater fish fre quenting the muddy rivers of the low lands, they are not relished by the more fastidious palate of the European.

RONERT W. S. MITCHELL

\section{THE DEVELOPMENT OF MOLLUSCA}

M R. RAY LANKESTER, in the current number of W the Quarterly 7ournal of Microscopical Scionce, gives the results of his examination of the embryo of the common Pond Snail (Limnaus stagnalis.) These are of great importance; first, because they show how much may be done by trained observation, with improved methods, of a very common form, which has already been studied by excellent anatomists; and secondly, because Mr. Lankester's previous investigations into the development of cuttles, Pisidium, and several marine gasteropods, enable him to form a sound judgment of the bearing of his discoveries upon questions of homology and of classification.

In Limnaus, Mr. Lankester finds that the process of segmentation (which is well illustrated by draswings of the egg in various positions at the several stages) is followed by the formation of a gastrula through a process of invagination. This gastrula (for Mr. Lankester adopts this term from Prof. Hreckel instead of "planula," the one he himself invented), with its double layer of cells and single orifice, develops into the next stage by the mouth closing and afterwards giving rise to the anus, while a fresh oral opening appears and a velum is developed. The presence of a velum in pulmonate Gasteropoda has not, we believe, been previously established, and is of great morphological importance. It is, Mr. Lankester believes, homologous with the trochal disc of rotifers, and he proposes the term "veliger" for the phase of development in which it appears. Nay, he gives reasons for regarding the subtentacular lobes of the adult Lymnaus as a residue of the velum. If it be so, it is the only instance yet known of this embryonic structure persisting in the perfect form.

The "anal cone" of M. Lereboullet is shown to have nothing to do with the anus, which is developed in the pedicle left by the obliterated gastrula-mouth. The functional import of the "aral-cone," or rather gland-sac, is still obscure. It has been already recognised by $\mathrm{Mr}$. Lankester in Pisidinm, Aphysia, and Neretina, and by Hermann Fol in embryo Pteropoda. It is possibly homologous with the basal gland described by Keferstein and Kowalevsky in Loxosoma among Bryozoa, and with a similar structure in Terebratula. The more difficult questions of its homoreny with the rudimentary intemal shell of the slug, and with the pensac of cuttles, are also discussed. One of the most curious facts about this "shell-gland" is that it frequently becomes filled with a homogeneous refracting secretion apparently chitinous in composition, which is a morbid, or at least an abuomal change, and associated with irregular development of the embryo.

Not the least valuable point established in this interesting memoir is that the rotation of the embryo Lymneus is caused by numerous short cilia on the annular band which afterwards forms the velum. The discovery of these cilia, which were sought by Lereboullet without success, is probably due to $\mathrm{Mr}$. Lankester having used perosmic acid, a reagent which is exceedingly useful in examining transparent Tunicata, and seems equally suited for displaying cilia anywhere,

The gastrula form appears apparently in all groups of animals but the highest and the lowest, in some form or other; but the "shell-gland" forms a valuable additional link between the Brachiopoda and Polyzoa on the one hand and the higher Molluscs on the other. If this be admitted, it is probable that Tunicata may be again admitted to the same great stem in spite of their undoubted affinities to vertebrates by Amplitoxys, and to worms by Balantoglossits.

It is a most satisfactory sign of the revival of embry. ology in England, that in the same number of the Quarterly Microscopical fournal which contains this important memoir by Mr. Lankester; there is also the preliminary account of the development of Elasmobranchii, by Mr. Balfour, which excited so much interest at the late meeting of the British Association. 